\title{
Possibilities of Using Fuel Cells for Energy Generation in Agricultural Greenhouses: A Case Study in Crete, Greece
}

\author{
John Vourdoubas ${ }^{1}$ \\ ${ }^{1}$ Mediterranean Agronomic Institute of Chania, Crete, Greece \\ Correspondence: John Vourdoubas, Mediterranean Agronomic Institute of Chania, Crete, Greece. Tel: \\ 30-282-1035-020. E-mail: vourdoubas@maich.gr
}

Received: February 27, 2019

Accepted: April 2, 2019 Online Published: June 15, 2019

doi:10.5539/jas.v11n8p113

URL: https://doi.org/10.5539/jas.v11n8p113

\begin{abstract}
The possibility of using fuel cells powered by solar hydrogen for energy generation in greenhouses with reference to the island of Crete, Greece has been examined. Change of fossil fuels used in greenhouses with renewable energies and sustainable energy technologies is very important for mitigation of climate change. Various renewable energy sources and low carbon emission technologies including geothermal energy, biomass, solar photovoltaics and co-generation systems have been used so far. Use of solar photovoltaics for generating electricity consumed in water electrolysis for hydrogen production has been investigated. Hydrogen feeding a proton exchange membrane fuel cell co-generating electricity and heat was used in a greenhouse located in Crete, Greece. The system could be useful in a stand-alone greenhouse with annual specific energy consumption at 150 $\mathrm{KWh} / \mathrm{m}^{2}$. A solar photovoltaic system with nominal power at $33.33 \mathrm{KW}_{\mathrm{p}}$ powering an electrolytic cell at 5.71 $\mathrm{KW}$ could produce annually $2,083 \mathrm{~kg}$ hydrogen. The hydrogen could feed a fuel cell at $1.71 \mathrm{KW}_{\text {el }}$ generating annually all the electricity required in a greenhouse of $1,000 \mathrm{~m}^{2}$. Co-produced heat could also cover $11.11 \%$ of the annual heat requirements in the greenhouse. It was found though that the overall electric efficiency of the system was very low at $4.5 \%$. The low overall efficiency and the size of the solar-PV required indicate that the abovementioned energy system is not suitable in commercial agricultural greenhouses.
\end{abstract}

Keywords: Crete-Greece, energy, fuel cells, greenhouses, hydrogen, solar energy, water electrolysis

\section{Introduction}

Modern agricultural greenhouses are energy-intensive production systems requiring large amounts of energy. In order to cope with climate change it is necessary to use non-conventional and low carbon emissions energy technologies instead of using fossil fuels in greenhouses. Various renewable energy technologies as well as efficient energy technologies, including solar energy, biomass, low-enthalpy geothermal fluids, co-generation systems and heat pumps, have been used, so far providing heat, cooling and electricity in them. However new emerging fuels like hydrogen $\left(\mathrm{H}_{2}\right)$ powering fuel cells $(\mathrm{FC})$ could be used in greenhouses, co-generating heat and power (CHP) for covering their energy needs. In the Mediterranean region where solar resources are abundant, solar-PV electricity can be used for $\mathrm{H}_{2}$ production with electrolysis of water. $\mathrm{H}_{2}$ could then be used in FCs for CHP. This results in the reduction of their carbon footprint and in the improvement of their sustainability.

\subsection{Energy Generation With Hydrogen and Fuel Cells}

Dodds et al. (2015) have reported on $\mathrm{H}_{2}$ and fuel cell technologies for heating. The authors stated that $\mathrm{H}_{2}$ and fuel cell technologies have been neglected as an alternative option for heating. They mentioned that fuel cell CHP has lower carbon emissions than natural gas-fuelled CHP systems while its cost is reducing. Therefore FC technologies consist of a viable option for heating in the near future. Genoglu et al. (2009) have reported on the design of a proton exchange membrane fuel cell (PEMFC) system for residential applications. The system consisted of solar-PV panels, batteries and an electrolyzer producing $\mathrm{H}_{2} . \mathrm{H}_{2}$ was stored in a tank and used by a PEMFC for electricity generation in the building. The authors estimated the nominal power of the PV panels at $2.5 \mathrm{KW}_{\mathrm{p}}$, and of the PEMFC at $4.8 \mathrm{KW}$. They concluded that small RES applications in residential buildings should include solar-PV panels, wind turbines and FCs. Gigliucci et al. (2004) have reported on a demonstration of a PEMFC suitable for residential applications either in stand-alone or in grid-connected buildings. The characteristics of the FC were: electric power $4 \mathrm{KW}$, thermal power $4.8 \mathrm{KW}$, electric efficiency $18 \%$ and total efficiency $50 \%$. The authors stated that the FC behaved as expected while its efficiency was low and it should be 
improved. They mentioned that its improvement does not require any major technological developments. Briguglio et al. (2011) have evaluated a low temperature fuel cell system for residential CHP. The authors investigated experimentally the heat recovery from a $5 \mathrm{KW}$ PEMFC working in a stack temperature at $71{ }^{\circ} \mathrm{C}$. They stated that hot water was obtained at $68{ }^{\circ} \mathrm{C}$ and it was removed with a heat exchanger under different power levels while the overall efficiency of the FC was up to $85 \%$. Nishimira et al. (2018) have investigated an integrated power generation system with solar-PVs and fuel cells for residential applications in seven Japanese cities. The authors considered that the electricity requirements of the households were covered with solar-PV electricity. The gap between electricity demand and solar electricity supply was covered with FC electricity based on hydrolytic $\mathrm{H}_{2}$ produced when solar electricity was in surplus. They concluded that the most appropriate number of households whose electricity demand could be fully covered by the integrated solar-PV and FC system was 16. Zabalza et al. (2007) have reported on the feasibility of using fuel cells in the tertiary sector in Spain. The authors stated that the high capital cost of FCs and the need to replace the FC stack every 6-7 years increase the cost of electricity generation. They concluded that an increase at $160 \%$ of the KWh price sold to the grid is required in order for the FCs to be competitive with other mature co-generation technologies. Chen et al. (2015) have reported on a 5 KW PEMFC-based residential micro-cogeneration cooling heat power (CCHP) system with absorption chiller. The authors described a micro tri-generation system driven by a PEMFC supplying electricity, hot water, space heating and space cooling to residences in summer and winter. They stated that the maximum efficiency of the system was $70.1 \%$ in the summer and $82 \%$ in the winter.

\subsection{Energy Demand and Use of Sustainable Energies in Agricultural Greenhouses}

Vourdoubas (2018) has studied the use of solar-PVs in grid-connected agricultural greenhouses with net-metering regulations in Greece. The author has estimated that the payback period of solar-PV investments in greenhouses varies between 7.2 and 14.4 years depending on the financial subsidy in their capital cost offered by the government. Gousgouriotis et al, 2007 have assessed the economic viability of biomass heating systems with reference to two agricultural greenhouses located in Chalkidiki, Northern Greece. The heating load of the greenhouses was $170 \mathrm{~W} / \mathrm{m}^{2}$ and the annual heat demand for a 5,000 $\mathrm{m}^{2}$ greenhouse was $1,519 \mathrm{MWh}$ (304 $\mathrm{KWh} / \mathrm{m}^{2}$ ). The authors stated that the initial cost of the biomass burning system is higher than the cost of the conventional heating system. However the lower biomass cost counterbalances its higher investment cost and the use of biomass is profitable. Vourdoubas, 2015 has presented a case study of an agricultural greenhouse using solid biomass as heating fuel in Crete, Greece. The author stated that the annual heating needs of the greenhouse were $220 \mathrm{KWh} / \mathrm{m}^{2}$ of covered area for keeping the indoor air temperature at $23{ }^{\circ} \mathrm{C}$. He also estimated that the use of heating energy had a share at $95.31 \%$ of the total energy consumption. Campiotti et al. (2012) have reported on sustainable greenhouse horticulture in Europe. The authors stated that the installed energy power load of greenhouses in Europe depends on local climate conditions and varies from $50-150 \mathrm{~W} / \mathrm{m}^{2}$ in southern Europe to 200-280 W/m ${ }^{2}$ in northern and central Europe while for complete air-conditioned greenhouses it could reach 400 $\mathrm{W} / \mathrm{m}^{2}$. They concluded that the prospects for growth of a sustainable greenhouse industry based on geothermal, biomass and solar-PV technologies are excellent. Tudisca et al. (2013) have reported on the Italian policy regarding the use of solar-PV systems in greenhouses. The authors have investigated the economics of a greenhouse located in Sicily that has installed solar-PVs according to the feed-in tariff regulations. They stated that due to high feed-in tariffs the solar-PV system was very profitable. Compernolle et al. (2011) have reported on the use of CHP systems in agricultural greenhouses for reducing $\mathrm{CO}_{2}$ emissions. The authors have implemented two case studies for lettuce and tomato crops. Their findings indicated that the CHP system was economically viable with positive NPVs in both crops while the profitability of the CHP system was influenced by its efficiency. Raslavicius et al. (2011) have reported on the benefits of small-scale CHP plants used in industrial greenhouses powered by liquid bio-fuels. The authors have studied the use of rapeseed oil as a fuel in small-scale CHP plants providing useful heat and electricity in greenhouses, indicating that it consists of a viable option in rural Lithuania. Rocamora et al. (2006) have reported on hybrid solar photovoltaic thermal (PV/T) system applications in greenhouses. The authors stated that the hybrid solar PV/T systems can be mounted on the greenhouse roof simultaneously providing heat and electricity. Electricity could be used in the greenhouse or sent into the grid while co-generated heat could be stored and used in the winter. Nayak et al. (2007) have reported on an integrated hybrid solar $(\mathrm{PV} / \mathrm{T})$ greenhouse system. The authors evaluated a hybrid solar PV/T collector integrated with a greenhouse with and without airflow. They stated that the overall efficiency of the hybrid solar PV/T system with airflow collector was $72 \%$ while it was $41 \%$ without an air collector.

\subsection{Use of Fuel Cells in Agricultural Greenhouses}

Gangualy et al. (2010) have studied the use of an integrated solar-PV-electrolyzer-fuel cell system for powering a stand-alone greenhouse located in Kalkuta, India. The authors stated that solar-PV panels with nominal power at 
$3.825 \mathrm{KW}_{\mathrm{p}}$ combined with a $3.3 \mathrm{KW}$ electrolyzer and a PEM fuel cell at $0.96 \mathrm{KW}_{\mathrm{el}}$ could cover all the energy demand of a $90 \mathrm{~m}^{2}$ floriculture greenhouse. Blanco et al, 2014 have experimented with a pilot solar-PV-electrolyzer-fuel cell system for powering a geothermal heat pump heating a stand-alone greenhouse in Italy. The heat pump was powered with electricity generated by a PEM fuel cell. Hydrogen was produced by an electrolyzer powered by a solar-PV system and stored in a tank. The authors stated that on partially cloudy days, the operation of the electrolyzer was intermittent with breakdowns in $\mathrm{H}_{2}$ production. On the contrary during the days with clear sky the electrolyzer was operating continuously. Anifantis et al. (2017) have reported on the thermal energy assessment of a small scale photovoltaic, hydrogen and geothermal stand-alone system for greenhouse heating. The authors used an experimental system located in Bari, Italy. Considering the efficiency of the solar-PV panels at $12 \%$, the electrolyzer at $48 \%$, the fuel cell at $40 \%$ and the coefficient of performance of the heat pump at 4.7 , the authors estimated the overall efficiency of the system at $11 \%$. They noted that this efficiency is rather low compared with the efficiency of solar thermal systems which is around $40 \%$. Sardella, 2013 has analyzed a fuel cell system for commercial greenhouse applications. The author has investigated the feasibility of integrating a PEM fuel cell with a commercial greenhouse. He stated that a $3 \mathrm{KW}$ fuel cell system can cover $25 \%$ of the electricity demand and $30 \%$ of the heating demand in a $1,000 \mathrm{~m}^{2}$ commercial greenhouse. Mulloney (1993) has reported on the use of fuel cells in large commercial greenhouses. The author stated that in the U.S. there already exist independent power plants producing power for the grid while the co-generated heat was used in large greenhouses. He proposed, alternatively, the use of fuel cells generating electricity, with high efficiency at $40-50 \%$, co-generating useful heat used in the greenhouses during the winter. The fuel cell would additionally tri-generate $\mathrm{CO}_{2}$ which could be used for enrichment of the indoor atmosphere in the greenhouse, increasing its productivity. Vadiee et al. (2015) have analyzed a fuel cell system for commercial greenhouse applications. The authors have estimated that a PEMFC at $11.6 \mathrm{KW}$ could cover the total annual electricity demand and $40 \%$ of the annual heat demand of a $1,000 \mathrm{~m}^{2}$ greenhouse. The electrical efficiency of the FC was $54 \%$ and its thermal efficiency $24 \%$. The authors suggested that it would be better if the FC would supply only part of the heating demand in the greenhouse instead of covering it totally. A large stationary Quad-gen fuel cell for power, heat, hydrogen and $\mathrm{CO}_{2}$ generation has been reported in the Fuel cells bulletin, 2014. According to this report an innovative project with a budget at US \$ 6.8 mil. has been developed in British Columbia. Landfill gas is cleaned by an innovative system and used by a molten carbonate fuel cell generating electricity, heat, hydrogen and $\mathrm{CO}_{2}$. Co-produced heat by the fuel cell and $\mathrm{CO}_{2}$ produced from landfill gas would be utilized by commercial greenhouses.

The aims of the current work are:

(a) The description of a sustainable energy system based on solar energy and $\mathrm{H}_{2}$ for covering the energy needs in a modern greenhouse;

(b) The calculation of the size of the required sustainable energy system.

\section{Hydrogen Production With Water Electrolysis and Solar Electricity}

Proton exchange membrane fuel cells operate in low temperatures generating electricity while the co-produced heat can be recovered and used. $\mathrm{H}_{2}$ can be produced with water electrolysis which is an old and mature technology that requires the use of electricity. It can be stored and used when needed for continuous electricity generation with fuel cells. If electricity used in electrolysis is generated by renewable energies, like solar-PV energy, its production does not generate any carbon emissions. Although the efficiency of solar-PV systems is low in the range of $15 \%$, solar electricity generation is currently competitive with electricity generated by fossil fuels. The efficiency of water electrolysis is higher than that of solar-PV modulus at around $75-80 \%$. Solar $\mathrm{H}_{2}$ production is an attractive option in areas with high solar energy resources like the Mediterranean region, particularly if the generated electricity is not needed during the time of high irradiance and its storage is necessary. Its storage as $\mathrm{H}_{2}$ is an alternative to its storage in electric batteries. Total efficiency of PEMFCs fuelled by $\mathrm{H}_{2}$ is high at around $80-85 \%$, depending on the ratio of power to heat generated. Their economics are more attractive if apart from electricity the co-produced heat could be used in various applications. Co-produced heat could be used for space cooling with the use of absorption cooling systems; in this case PEMFCs operate as tri-generation systems. Stationary PEMFCs can be used in various applications although they are not yet fully commercialized.

\section{Energy Requirements in Greenhouses}

Modern agricultural greenhouses require energy for covering their needs in heating, cooling and lighting, and in the operation of various electric devices and machinery. Their energy requirements depend on various factors including the type of construction, the local climate and the cultivated crop. Annual energy requirements in 
southern European countries are lower compared with northern European countries. Some "village type" greenhouses in the Mediterranean region used for vegetable production with low yields have low energy requirements since they are not heated at all or they are partly heated. The main energy sources and fuels used in modern greenhouses are electricity, oil and natural gas. Renewable energy sources, if available, are occasionally used for heating including solid biomass and geothermal fluids at temperatures of $50-80{ }^{\circ} \mathrm{C}$. Ground source heat pumps are energy-efficient devices with COPs of around 3-4 for heating and cooling but due to their high capital cost their use is rather limited so far. Very efficient CHP systems with overall efficiencies at $85-90 \%$ are also used in industrial greenhouses, usually fuelled by natural gas. Solar-PV systems are also used for electricity generation with net-metering regulations, particularly in recent years after the sharp drop in the prices of PV modulus, although their efficiency is low at around $15 \%$. In modern greenhouses in southern Greece, control of the indoor temperature over the year requires large amounts of energy while the share of heat energy could exceed $90 \%$ in the total energy mix.

\section{Sizing Fuel Cells Covering Annual Energy Requirements in Greenhouses}

An autonomous energy system based on solar energy, $\mathrm{H}_{2}$ and in FCs generating zero carbon emission electricity and heat for stand-alone greenhouses located in Crete, Greece has been examined and the size of the energy systems has been calculated. The energy system consists of:

(a) A solar-PV system generating electricity;

(b) A water electrolyzer using the generated solar electricity for $\mathrm{H}_{2}$ production which is stored in a tank, and

(c) A PEMFC using $\mathrm{H}_{2}$ and producing electricity covering all the annual electricity requirements in the greenhouse. Co-produced heat could cover part of its heating needs.

The following assumptions have been made:

(a) The covered area of the greenhouse is $1,000 \mathrm{~m}^{2}$ and its specific energy consumption is $150 \mathrm{KWh} / \mathrm{m}^{2}$. The share of electricity in the energy mix is $10 \%$ and of heat $90 \%$. Electricity demand in the greenhouse is constant during the year. The $\mathrm{FC}$ will generate all the electricity annually required in the greenhouse;

(b) The electric efficiency of the FC is $40 \%$ and its heat efficiency is $40 \%$;

(c) Average energy of hydrogen is $36 \mathrm{KWh} / \mathrm{kg}$ while its density at $700 \mathrm{bar}$ is $42 \mathrm{~kg} / \mathrm{M}^{3}$;

(d) The fuel cell operates 8,760 hours/year.

Energy requirements and energy generation by the FC are presented in Table 1.

Table 1. Size of the FC for energy generation

\begin{tabular}{ll}
\hline Annual electricity generation by the FC & $15.000 \mathrm{KWh}_{\mathrm{el}}$ \\
\hline Annual heat generation by the FC & $15,000 \mathrm{KWh}_{\mathrm{th}}$ \\
Additional heat required in the greenhouse & $120,000 \mathrm{KWh}_{\mathrm{th}}$ \\
Total annual energy generation by the FC & $30,000 \mathrm{KWh}$ \\
$\%$ of annual heating needs covered & $11.11 \%$ \\
Size of FC & $1.71 \mathrm{KW}_{\mathrm{el}}$ \\
Annual hydrogen requirements & $2.083 \mathrm{Kg}$ \\
Volume of the $\mathrm{H}_{2}$ at 700 bar & $49.6 \mathrm{M}^{3}$ \\
\hline
\end{tabular}

\section{Sizing of the Solar-PV System Producing the Hydrogen Required in the Fuel Cell With Water Electrolysis}

The annually required hydrogen in the FC could be produced with water electrolysis powered with solar electricity generated by a solar-PV system. In order to calculate the size of these systems the following assumptions have been made:

(a) Annual electricity generation by a solar-PV system in Crete, Greece is $1,500 \mathrm{KWh}$ per $\mathrm{KW}_{\mathrm{p}}$;

(b) Energy efficiency of water electrolysis is $75 \%$;

(c) Efficiency of the solar-PV system is $15 \%$;

(d) Operation of electrolysis is 8,760 hours/year; 
(e) Overall electric efficiency of the system is the product of the efficiency of the solar-PV system, water electrolysis and the electric efficiency of the FC. Overall energy efficiency in hydrogen production is the product of the efficiency in the solar-PV and in water electrolysis.

The size of the required solar-PV system generating the required power for water electrolysis and $\mathrm{H}_{2}$ production is presented in Table 2 .

Table 2. Size of the solar-PV system required for the production of solar $\mathrm{H}_{2}$ used in the FC

\begin{tabular}{ll}
\hline Energy of solar hydrogen produced annually & $37,500 \mathrm{KWh}$ \\
\hline Annual electricity requirements in water electrolysis & $50,000 \mathrm{KWh}$ \\
Power of water electrolyzer & $5.71 \mathrm{KW}$ \\
Nominal power of the solar-PV system generating the electricity annually required in water electrolysis & $33.33 \mathrm{KW}_{\mathrm{p}}$ \\
Efficiency of solar hydrogen generation & $11.25 \%$ \\
Overall electric efficiency & $4.5 \%$ \\
Overall heat efficiency & $4.5 \%$ \\
Overall total efficiency of heat and power co-generation & $9 \%$ \\
\hline
\end{tabular}

\section{Advantages and Drawbacks of the Above-Mentioned Energy System Used in Agricultural Greenhouses}

A solar-PV system combined with $\mathrm{H}_{2}$ production via water electrolysis and energy generation with a PEMFC could be used for covering part of the energy needs in a stand-alone greenhouse. Although this system is currently technically feasible it is not economically viable. However it could provide carbon-free energy in greenhouses promoting their environmental sustainability and contributing to the mitigation of climate change. When hydrogen production technologies are mature and the use of FCs is fully commercialized, these energy systems could be used in various applications including in stand-alone agricultural greenhouses. The above-mentioned autonomous energy system has various advantages as well as drawbacks which are presented in Table 3.

Table 3. Advantages and drawbacks of the above-mentioned energy system

\begin{tabular}{ll}
\hline Advantages & Drawbacks \\
\hline $\begin{array}{l}\text { The described system could be used in stand-alone greenhouses } \\
\text { resulting in zero carbon emissions due to electricity use }\end{array}$ & Operation of PEMFCs for general use is still expensive \\
$\begin{array}{l}\text { Solar-PV and water electrolysis are mature technologies. } \\
\text { PEMFCs are expected to be cost-effective in the near future }\end{array}$ & The system has a low overall electric and thermal efficiency \\
$\begin{array}{l}\text { The system can be useful in areas with high solar irradiance } \\
\text { located away from electric grid infrastructure }\end{array}$ & $\begin{array}{l}\text { The system is suitable only for specific applications } \\
\text { Although the technical feasibility of such systems can be established, } \\
\text { their economics are not currently favorable } \\
\text { The co-generated heat cannot be used in the summer in the } \\
\text { greenhouse except if it could be combined with an absorption } \\
\text { cooling system }\end{array}$ \\
\hline
\end{tabular}

\section{Discussion}

Co-generation systems fuelled with natural gas are currently used for energy generation in large commercial greenhouses. Use of renewable energy sources in them is desirable for economic and environmental reasons. Solid biomass and low enthalpy geothermal energy are already used for heat generation in greenhouses worldwide. The recent sharp decrease in the price of solar-PVs favors their use for power generation. Studies on the use of hybrid solar PV/T co-generation systems in greenhouses have been reported although commercial applications have not been found. Various feasibility studies regarding the use of FCs in agricultural greenhouses have been published presenting their advantages, drawbacks and their future prospects. However the current high cost of FCs does not favor their use in various applications. Integration of solar-PVs with FCs results in low overall energy efficiencies which increases their cost and does not favor their commercial use. Their technical feasibility has been established though and the technologies of solar-PVs, water electrolysis for $\mathrm{H}_{2}$ production and FCs are well known. Future prospects of using solar-PVs with FCs in small residential applications are 
positive. Therefore the use of similar energy systems in agricultural greenhouses could be an economically viable solution in specific cases in the future.

\section{Conclusions}

A sustainable energy system based on solar energy and $\mathrm{H}_{2}$ covering the energy needs in greenhouses has been described. The system is consisted of an electrolytic cell fuelled by solar-PV electricity for $\mathrm{H}_{2}$ generation. $\mathrm{H}_{2}$ is then fed in a PEMFC co-generating electricity and heat used in an agricultural greenhouse. The covered area of the greenhouse was $1,000 \mathrm{~m}^{2}$ with specific annual energy consumption at $150 \mathrm{KWh} / \mathrm{m}^{2}$ located in Crete, Greece. The nominal power of the solar-PV system was $33.33 \mathrm{KW}_{\mathrm{p}}$ while the power of the electrolytic cell was $5.71 \mathrm{KW}$ producing annually $2,083 \mathrm{~kg} \mathrm{H}_{2} . \mathrm{H}_{2}$ was fed in a PEMFC at $1.71 \mathrm{KW}_{\mathrm{el}}$ generating all the required electricity in the greenhouse at $15,000 \mathrm{KWh} /$ year. Co-produced heat by the PEMFC can also cover $11.11 \%$ of its annual heat requirements. The overall electric efficiency of the energy system was low at $4.5 \%$ and the size of the solar-PV required relatively large. These results indicate that the abovementioned sustainable energy system is not suitable for commercial agricultural greenhouses but probably only for stand-alone greenhouses located in areas with high solar irradiance and without electric grid infrastructure. Further work should be focused in the implementation and operation of the abovementioned energy system in a greenhouse and the assessment of its performance.

\section{References}

Anifantis, A. S., Colantoni, A., \& Pascuzzi, S. (2017). Thermal energy assessment of a small scale photovoltaic, hydrogen and geothermal stand-alone system for greenhouse heating. Renewable Energy, 103, 115-127. https://doi.org/10.1016/j.renene.2016.11.031

Blanco, I., Pascuzzi, S., Anifantis, A. S., \& Scarascia-Mugnozza, G. (2014). Study of a pilot photovoltaic-electrolyzer-fuel cell power system for a geothermal heat pump heated greenhouse and evaluation of the electrolyzer efficiency and operational mode. Journal of Agricultural Engineering, 238, 111-118. https://doi.org/10.4081/jae.2014.238

Briguglio, N., Ferraro, M., Brunaccini, G., \& Antonucci, V. (2011). Evaluation of a low temperature fuel cell system for residential CHP. International Journal of Hydrogen Energy, 13, 8023-8029. https://doi.org/ 10.1016/j.jijhydene.2011.01.050

Campiotti, C., Viola, C., Alonzo, G., Bibbiani, C., Giagnacovo, G., Scoccianti, M., \& Tumminelli, G. (2012). Sustainable greenhouse horticulture in Europe. Journal of Sustainable Energy, 3(3).

Chen, X., Gong, G., Wan, Z., \& Luo, L. (2015). Performance analysis of 5 KW PEMFC-based residential micro-CCHP with absorption chiller. International Journal of Hydrogen Energy, 40, 10647-10657. https://doi.org/10.1016/j.ijhydene.2015.06.139

Compernolle, T., Witters, N., Van Passel, S., \& Thewys, T. (2011). Analyzing a self-managed CHP system for greenhouse cultivation as a profitable way to reduce $\mathrm{CO}_{2}$ emissions. Energy, 36, 1940-1947. https://doi.org/10.1016/j.energy.2010.02.045

Dodds, P. E., Staffell, I., Awkes, A. D., Li, F., Grunewald, Ph., McDowall, W., \& Ekins, P. (2015). Hydrogen and fuel cell technologies for heating: A review. International Journal of Hydrogen Energy, 40, 2065-2083. https://doi.org/10.1016/j.ijhydene.2014.11.059

Ganguly, A., Misra, D., \& Ghosh, S. (2010). Modeling and analysis of solar photovoltaic-electrolyzer-fuel cell hybrid power system integrated with a floriculture greenhouse. Energy and Buildings, 42, 2036-2043. https://doi.org/10.1016/j.enbuild.2010.06.012

Genoglu, M. T., \& Ural, Z. (2009). Design of a PEM fuel cell system for residential application. International Journal of Hydrogen Energy, 34, 5242-5248. https://doi.org/10.1016/j.ijhydene.2008.09.038

Gigliucci, G., Petruzzi, L., Cerelli, E., Garzisi, A., \& La Mendola, A. (2004). Demostration of a residential CHP system based on PEM fuel cells. Journal of Power Sources, 31, 62-68. https://doi.org/10.1016/j.jpowsour. 2004.01.010

Gousgouriotis, I. J., Katsigiannis, Y. A., \& Georgilakis, P. S. (2007). Economic evaluation of biomass heating systems: A case of greenhouses in northern Greece. Operational Research: An International Journal, 7(1), 37-58. https://doi.org/10.1007/BF02941187

Mulloney, J. A. (1993). Mitigation of carbon dioxide releases from power production via "sustainable agri-power": The synergistic combination of controlled environmental agriculture (large commercial 
greenhouses) and disbursed fuel cell power plants. Energy Conversion and Management, 34(9-11), 913-920. https://doi.org/10.1016/0196-8904(93)90036-A

Nayak, S., \& Tiwari, A. (2007). Performance evaluation of an integrated hybrid photovoltaic thermal (PV/T) greenhouse system. International Journal of Agricultural Research, 2, 211-226. https://doi.org/10.3923/ ijar.2007.211.226

Nishimura, A., Tanikaga, S., Hirota, M., \& Hu, E. (2018). Energy characteristics of an integrated power generation system with photovoltaic and fuel cell. Smart Grid and Renewable Energy, 9, 57-73. https://doi.org/10.4236/sgre.2018.94005

None. (2014). Quad-gen fuel cell for power, heat hydrogen, $\mathrm{CO}_{2}$ for greenhouses. Fuel Cells Bulletin, 2014(4), 5-6. https://doi.org/10.1016/S1464-2859(14)70103-8

Raslavicius, L., \& Straksas, A. (2011). Motor bio-fuel-powered CHP plants-a step towards sustainable development of rural Lithuania. Technological and Economic Development of Economy, 17(1), 189-205. https://doi.org/10.3846/13928619.2011.560639

Rocamora, M. C., \& Tripanagnostopoulos, Y. (2006). Aspects of PV/T solar system application for ventilation needs in greenhouses. Acta Hort., 719, 239-246. https://doi.org/10.17660/ActaHortic.2006.719.26

Sardella, M. (2013). Energy analysis of a fuel cell system for commercial greenhouse applications (M.Sc. Thesis, KTH School of Industrial Engineering and Management, Stockholm, Sweden). Retrieved January 30, 2019, from http://www.diva-portal.org/smash/get/diva2:611888/FULLTEXT01

Tudisca, S., DiTrapani, A. M., Sgroi, F., Testa, R., \& Squatrito, R. (2013). Assessment of Italian energy policy through the study of a photovoltaic investment on greenhouse. African Journal of Agricultural Research, 8(24), 3089-3096. https://doi.org/10.5897/AJAR2013.7406

Vadiee, A., Yaghoubi, M., Sardella, M., \& Farjam, P. (2015). Energy analysis of fuel cell system for commercial greenhouse application-A feasibility study. Energy Conversion and Management, 89, 925-932. https://doi.org/10.1016/j.enconman.2014.09.073

Vourdoubas, J. (2015). Overview of heating greenhouses with renewable energy sources: A case study in Crete-Greece. Journal of agricultural and Environmental Sciences, 4(1), 70-76. https://doi.org/10.15640/ jaes.v4n1a9

Vourdoubas, J. (2018). Economic assessment of solar photovoltaic use in Agricultural greenhouses in Greece. Journal of Agricultural Studies, 6(4), 23-35. https://doi.org/10.5296/jas.v6i4.13896

Zabalza, I., Aranda, A., \& De Gracia, M. D. (2007). Feasibility analysis of fuel cells for combined heat and power systems in the tertiary sector. International Journal of Hydrogen Energy, 32, 1396-1403. https://doi.org/10.1016/j.ijhydene.2006.10.019

\section{Copyrights}

Copyright for this article is retained by the author(s), with first publication rights granted to the journal.

This is an open-access article distributed under the terms and conditions of the Creative Commons Attribution license (http://creativecommons.org/licenses/by/4.0/). 